\title{
DA INCOMPETÊNCIA
}

\author{
Armando Freitas Filho
}

Todo ser humano tem um leque vocacional. As circunstâncias da vida é que vão determinar a escolha e o grau de investimento que ele vai poder dar a essas inclinações de origem.

Por isso, o acaso tem uma presença importante nesta questão. Não basta a vontade pura e simples, mas o alimento casual que fortalecerá, para o bem ou para o mal, o desenvolvimento dessas tendências, que acabam se reunindo num fruto que cresce na estufa e ao ar livre, ao mesmo tempo. $\mathrm{O}$ lado que controla esse desempenho, além dos impulsos naturais, sofrerá percalços de todo o tipo: desânimo eventual, náusea, ameaça de atrofia, inapetência. Neste momento, o lado que está fora do controle ou "fora de si” poderá intervir (ou não), positiva ou negativamente.

No meu caso, com o conhecimento adquirido de mim mesmo, conhecimento perturbado pelo pânico de quem completou sete décadas de vida (e, portanto, mais perto do fim) posso dizer, sem mistificar, que o feixe da minha vocação foi mantido, com suas particularidades afins, pois desde criança sempre gostei de escrever.

Nesse percurso, contudo, ocorreu uma perversão contínua, ocasionada, a princípio, por um medo, por uma de falta de força e de fé em mim mesmo, que me tornava inapto para qualquer competição normal que a vida proporciona, e que foi como que me aleijando: à medida que era seguidamente derrotado, não na luta, mas na desistência, fui obrigado a acreditar numa fantasia ou num dom, mais inventado do que sentido, para salvar-me. Este esforço de transformar uma ilusão possível numa 
realidade praticável me tornou quase cego, para o exercício cotidiano, no mundo dos outros. O resultado é que desaprendi ou fui deixando de aprender várias coisas que me fazem falta no dia a dia geral, comunitário, que dariam, inclusive, à futura profissão de escritor, maior amplitude.

Esta incompetência crescente não era necessária, mas acabou sendo, para mim, vital. Precisei desse fanatismo, desse fundamentalismo neurótico, do seu motor envenenado, para enfrentar, com uma espécie de estoicismo além da conta, a resistência, a descrença, o silêncio da família. Optei pela posição negativa absoluta, de "contrastes e confrontos", como quem aposta sem dinheiro, precisando blefar durante todo o tempo: na mesa do café, do almoço e do jantar, em vez de tentar o convencimento que, apesar de difícil, teria sido mais rico, sob o ponto de vista existencial e intelectual. Acreditei que antes só que bem acompanhado no traçado do destino, que por um misto de desobediência e covardia, no início sem causa definida com clareza, e depois com alguma orientação, fui entortando, mas sem nunca saber ao certo o porquê desta atitude, em virtude de sua radicalidade de não contra-argumentar, e aonde ela me levaria, sem nenhuma mediação: ao que era esperado pelo clã de alguma maneira, mais ou menos, ou a um descaminho dessa expectativa. Logo eu, muito mais próximo da rotina do que da aventura.

De todo modo, o ganho foi maior que a perda, preciso crer. Se não consegui manter a interação com o entorno de forma consistente e sistemática, minha vocação cresceu, de forma atípica, na sua voracidade: buraco negro, papel sem fim, sem distração, nem desvio desta espécie de canteiro de obras ou das atividades a ele inerentes. Contrapus ao personagem aguado do diletante, o do autodidata concentrado, sem autonomia, a não ser a que se presta a esse fim único. Em ambos há desperdício de élan: no primeiro, por diluir-se ou evaporar-se em paixões voláteis, sem raízes genuínas na sua história, e no segundo, por ter que se empenhar, como que em dobro, para alcançar o pretendido. Pelo menos, pude ocupar minha vida com o aprendizado obstinado, sem norma e sustentação aparente.

O que era viço, portanto, virou vício, com os perigos próprios desta condição. Sem atinar direito como proceder com eficácia, fugi do que se assemelhava a uma paralisia e mesmice familiar, em todos os sentidos: com os de sangue e com os de convívio estreito, preferindo correr o risco de cair, não no seu oposto, mas no espaço infinito da mania, do cacoete, da repetição, que não é a outra face da moeda, mas a mesma. Esse perigo sempre foi perceptível, sinal de que, em algum nível da realidade, ele está ativo. Não sei como tratar ou curar essa sensação (ou esta morte) de estar preso a um destino pétreo. Nem sei se há tratamento, cura, se há, ainda, 
lugar e tempo para a antiga ilusão ventilar-se mais, com algum proveito, mesmo que mínimo.

Talvez se não tivesse me "despreparado" tanto, de maneira tão obsessiva e redutora, me "profissionalizado" com tamanha dureza, se, enfim, fosse mais amador, etimologicamente falando, os recursos para conhecer, combater e relativizar a possível gravidade desse sintoma não estariam, hoje, longe do meu alcance, da minha sabedoria e esperança, e o meu rendimento seria melhor, ou menos afobado e carente, suponho.

Todo esse falatório para chegar, calculo que mais por cansaço do que por outra coisa, à conclusão batida de que o caminho é feito e se faz, através e apesar de nós mesmos: estamos ao léu, ao tempo, embora achemos que há um teto que nos cobre e uma casa que nos cerca, mesmo sabendo que, se for assim, será mais por hábito do que por amor. 
